\title{
TRAINING COURSES
}

Designed primarily for geoscientists from developing countries and run mainly on a post-graduate level.

- Signifies first announcement in EPISODES.

\section{6}

July 21, 1486 - February 27,1987

REMOTE SENSING AND ITS APPLICATION TO VARIOUS THEMES (WATER RESOURCES, MINERAL RESOURCES, TERRAIN EVALUATION AND LAND USE PLANNING) (Bombay, Indit). 32-week course organized by Centre of Studies in Resources Engineering, II'l', and designed to train in service engineers and scientists in the area of fundimentals of satellite remote sensing.

For Information: ])r. T.V. Pavate, Chief Project Engincer, Training, Extension and Project Cell, K.S.L. No. VI, C.S.R.E., IIT, Bombay - 400076 , India.

September 1986 - October 1986

REMOTE SENSING: FUNDAMENTALS OF APPLICATIONS AND ANALYSIS TECHNIQUES, 25th International Workshop. (Sioux Falls, South lakota, U.S.A.). Program of training workshops organized by the U.S. Geological Survey for non-U.S. scientists, engineers, and resources managers.

For Information: Training Section, Office of International Geology, U.S. Geological Survey, 917 National Center, Reston, VA 22092 , U.S.A.

September 1986 - October $1986^{\circ}$

GEOLOGIC AND HYDROLOGIC HAZARUS (Denver, Colorado, U.S.A.). A training program organized by the U.S. Geological Survey for international participants from disaster-prone countries.

For Information: U.S. Geological Survey, Training Section, 917 National Center, Reston, Virginia 22092, U.S.A.

September 1986 - November 1986

DRILLING OF GEOTHERMAL WELLS (Vexicali, Vexico). Annual 12-week seminar organized for Latin Americans by the Latin American Organization for Energy with financial assistance froir Unesco. Language: Spanish.

For Information: Organizacion Latinoamericana de Enereria (OLADE), P.O. Box 199, Quito, Ecuador.

September 1986 - November 1986

GEOTHERMAL RESERVOIR ENGINEERING (Mexicali, Mexico). Annual 9-week course organized for Latin Americans by the Latin American Organization for Energy with financial assistance from Unesco. Language: Spanish.

For Information: Organizacion Latinoamericana de Energia (OLADE), P.O. Box 119 , Quito, Ecuador.

September 1986 - November 1986

GEOTHERMAL ENERGY (Kyushu, Japan). Annual short course organized by the Government of Japan and sponsored by Uneseo. Language: English.

For Information: Japan International Cooperation Agency (2nd Training l)ivision, Training Affuirs bepartment), P.O. Box 216 , Shinjuku hitsui Building, 2 - 1, Nishi-shinjuku, Shinkuku-ku, Tokyo 160, Japan.

September 1986 - June 1987

REMOTE SENSING TRAINING (Toulouse, France). A diploma course with options for geoscientists sponsored by the French Aerospace Remote Sensing Development Organization (GDTA), BRGiv, IFP and other French institutions. language: French.

For Information: GDTA-Formation, 18 avenue Edouard-Belin, 31055 Toulouse Cedex, France.
September 1986 - July 1987

- PETROLEUM EXPLORATION GEOLOGY (Headington, Oxford, U.K.). A diploma course designed by Oxford Polytechnic to prepare post-graduate geologists for the duties of geologists in oil exploration teams.

For Information: Dr. H. Hoggins, Department of Geology and Physical Seiences, Oxford Polytechnic, Headington, Oxford OX3 $0 \mathrm{BP}$, U.K.

Septernber 1986 - August 1987

MINING EXPLORATION AND EXPLORATION GEOPHYSICS (Delft, The Netherlands). Annual diploma courses organized by the International Institute for Aerial Survey and Earth Sciences and sponsored by Unesco. Language: English.

For Information: ITC (ME), P.O. Box 6, 7500 A $A$ Enschede, The Netherlands.

October 1986

- apPlications of NUClEAR GEOPHYSICS IN THE EXPLORATION AND EXPLOITATION OF NATURAL RESOURCES (Hyderabad, India). International Atomic Energy Agency Training Course. Language: English.

For Information: IAEA Training Courses Section, Division of Technical Assistance and Co-operation, P.O. Box 100, A-1400 Vienna, Austria.

October 1986 - November 1986

TECTONICS, SEISMOLOGY AND SEISMIC RISK ASSESSMENTS (Potsdam, East Germany). One-month training course organized annually by East German Academy of Sciences in collaboration with Unesco. Language: English.

For Information: Prof. Dr. H. Kautzleben, Director, Central Earth's Physics Institute, Academy of Sciences of the German Democratic Republic, Telegraphenberg, DDR 1500 Postdam, German Democratic Republic.

October 1986 - July 1987

ENGINEERING HYDROLOGY (Galway, Ireland). Annual diploma and post-graduate courses organized by the Department of Engineering Hydrology, University College Galway, Ireland. Sponsored by Unesco-IHP and the World Vleteorological Organization. For Information: Prof. J.E. Nash, Department of Engineering Hydrology, University College Galway, Galway, Ireland.

October 1986 - September 1987

WATER AND WASTE ENGINEERING FOR DEVELOPING COUNTRIES (Loughborough, England, U.K.). Fwelve-month WSe programme organized annually for engineers and scientists from developing countries by $W E D C$.

For Information: John Pickford, WEuC Group Leader, University of Technology, Loughborough, Leies. LE 11 3TU, U.K.

October 1986 - September 1987

HYDRAULIC ENGINEERING AND HYDROLOGY (Delft, The Netherlands). Diploma courses organized annually by the International Institute for Hydraulic and Environmental Engineering and sponsored by Unesco for professionals from developing countries. Language: English.

For Information: International Institute for Hydraulic and Environmental Engineering (IHE), Oude Delft 95, P.O. Box 3015, 2601 DA Delft, The Netherlands.

October 1986 - September 1988

FUNDAMENTAL AND APPLIED QUATERNARY GEOLOGY (Brussels, Belgium). Annually organized training course leading to a Master's degree in Quaternary Geology by the Vrije Universiteit Brussel (IFAQ) and sponsored by Unesco. Language: English.

For Information: Prof. 1)r. R. Paepe, Director of IFAQ, Kwartairgeologie, Vrije Universiteit Brussel, Pleinlaan 2, B-1050, Brussels, Belgiun.

November 1986 - December 1986

REMOTE SENSING APPLICATIONS COURSE

FOR EARTH SCIENCES (Enschede, The Netherlands). Annual course organized by International Institute for Aerial Survey and Earth Sciences and sponsored by uneseo. Language: English.

For Information: ITC Student Registration Office, P.O. Box 6, 7500 AA Enschede, The Netherlands.

November 1986 - December 1986

SMALL MINE POTENTIAL AND TECHNOLOGY (Leoben, Austria). Annual training course sponsored by Austria and Unesco. Language: English.

For Information: Prof, Wolf'bauer, Forschungsgesellschaft Jounneum, Roseggerstrasse is, A-8700 Leoben, Austria.

November 1986 for two 11-month sessions ENGINEERING GEOLOGY (Delft, The Netherlands). New post-graduate diploma course leading to W.Sc. degree in Engineering Geology.

For Information: ITC Student Registration Office, P.O. Box 6, 7500 AA Enschede, The Netherlands.

November 1986 - June 1987

GEOTHERMICS (Pisa, Italy). Certificate course organized annually by the Istituto internazionale per le Ricerche (jeotermiche and sponsored by Uneseo, UNDP and Italy. Language: English.

For Information: Istituto Internazionale per le Ricerche Geotermiche, 1 Via Buongusto, 56100 Pisa, Italy.

December 1986 - January 1987

METHOOS AND TECHNIQUES IN EXPLORATION GEOPHYSICS (Hyderabad, India). Diploma course organized annually by the National Geophysical Research Institute of the Council of Scientific and Industrial Research, Hyderabad, India, and sponsored by Unesco. Language: English.

For Information: The Director, International Training Course on Methods and Techniques in Geophysical Exploration, National Geophysical Research Institute, Hyderabad, 500007 (A.P.) ndia.

\section{7}

January 1987 - April 1987

DIGITAL IMAGE PROCESSING (Enschede, The Netherlands). Certificate courses on techniques for hational resources surveys, organized annually by the International Institute of Aerial Surveys and Earth Sciences (ITC). Sponsored by Unesco. Language: English.

For Information: ITC Student Affairs office, P.O. Box 6, 7500 AA Enschede, The Netherlands.

February 1987

METALLOGENY (Quito, Eeuador). Annual 3-week training course for Latin Americans organized by Central University of Quito, the Autonomous University of Madrid (Spain), and Unesco. Language: Spanish.

For Information: Director, Curso Internacional de Metalogenia, Escuela de Geologia, Minas y Petroleos, Division de Post-grado, Universidad Central, Apartado Postal 8779, Quito, Ecuador.

February 1987 - March 1987

GEOCHEMICAL PROSPECTING TECHNIQUES (Tervuren, Belgium). Annual course sponsored by the Royal Museum of Central Africa and UNDP. Language: French. 
For Information: Musée roval de l'Afrique centrale, Steenveg op Leuven, 13, B-1980 Tervuren, Belgium.

February 1987 - June 1987

MINERAL EXPLORATION (Leoben, Austria). Diploma course organized annually by the University of Mining and Metallurgy in Leoben and sponsored by Unesco. Language: English. For Information: University for Mining and Vetallurgy, Postgraduate course on mineral exploration, Montanuniversität, Leoben, A-8700, Austria.

February 1987 - November 1987

PHOTOINTERPRETATION APPLIED TO GEOLOGY AND GEOTECHNICS (Bogota, Colombia). Diploma course organized by the Government of Colombia, Interamerican Centre of Photointerpretation, International Institute for Aerial Survey and Earth Sciences and Unesco. Language: Spanish.

For Information: Academic Secretariat of the CIAF, Apartado Aereo 53754, Bogota 2, Colombia.

Warch 1987 - April 1987

MINERAL EXPLORATION (Paris, France). A 4 -week annual course organized annually by the Ecole Nationale Supérieure des Mines and sponsored by Unesco. Language: French.

For Information: Prof. $\mathrm{H}$. Pélissonnier, Ecole des Mines, 60 Bd Saint Michel, 75272 Paris, Cedex 06, France.

April 1986 - July 1987

RURAL GROUNDWATER DEVELOPMENT (Loughborough, U.K.). A l0-week diploma course organized annually by WEDC.

For Information: WEDC, University of Technology, Loughborough LEI 1 3TU, U.K.

May 1987 - June 1987

GEOPHYSICS APPLIED TO GEOTHERMAL PROSPECTION (Manizales, Colombia). Annual course organized for Latin Americans by the Letin American Organization for Energy with financial assistance from Unesco. Language: Spanish.

For Information: Organizacion Latinoamericana de Energia (OLADE), P.O. Box 119, Quito, Ecuador.

May 1987 - November 1987

GENERAL HYDROLOGY with emphasis on groundwater (Argentina). Post-graduate course organized every other year and sponsored by Unesco. Language: Spanish.

For Information: Comité Nacional para el Programa Hidrologico Internacional de la Republica Argentina, Av 9 de Julio 1925 - $15^{\circ}$ piso, 1332 Buenos Aires, Argentina.

June 1987 - August 1987

TECHNIQUES OF HYDROLOGIC INVESTIGATIONS (Washington, D.C. and Denver, Colorado, U.S.A.). Annual training course for international participants.

For Information: Office of International Hydrology, Water Resources Division, U.S. Geological Survey, 470 National Center, Reston, Virginia 22092 , U.S.A.

July 1987 - August 1987

SUMMER COURSE ON EARTH SCIENCES: CRYSTALLOGRAPHY, MINERALOGY, METALLOGENY (Madrid, Spain). Annual course organized by the Department of Geology and Geochemistry of the Universidad Autonoma de Madrid and sponsored by Unesco. Language: Spanish.

For Information: Prof. T, Monseur, Departamento de Geologia y Geoquimica, Facultad de Ciencias, Universidad Autonoma de Madrid, Canto Blanco, Madrid 34, Spain.

July 1987 - September 1987

VOLCANOLOGY (Quito, Ecuador). Annual 10week course organized for Latin Americans by the Latin American Organization for Energy with financial assistance from Unesco. Language: Spanish.
For Information: Organizacion Latinoamericana de Energia (OLADE), P.O. Box 119 Quito, Ecuador.

August 1987 - June 1989

SOIL SCIENCE AND WATER MANAGEMENT (Wageningen, The Netherlands). A 2-year M.Sc. course organized by Agricultural University Wageningen. Course starts every other year. Language: English.

For Information: The Director of Studies of the M.Sc. Course in Soil Science and Water Management, P.O. Box 37, 6700 AA Wageningen, The Netherlands.

August 1987 - October 1987

GEOCHEMICAL PROSPECTING METHODS (Prague, Czechoslovakia). Certificate course organized every second year by the Geological Survey of Czechoslovakia and sponsored by Unesco, IAGC and Czechoslovakia. Language: English.

For Information: GEOCHIiv Unesco CSSR, Geologieal Survey of Prague, Malostranské nam. 19, 11821 Prague 1, Czechoslovakia.

September 1987 - October 1987

GROUNDWATER TRACING TECHNIQUES (Graz, Austria). Five-week course organized every other year by the Institute of Technical Geology, Petrography and Mineralogy and sponsored by Unesco. Language: English.

For Information: Institute of Technical Geology, Petrography and Mineralogy of the University of Technology, A-8010 Graz, Austria.
OTHER TRAINING PROGRAMS

DESERT STUDIES (N egev, Israel). Courses, seminars and workshops in Desert Hydrology and related topics organized by The Blaustein International Center for Desert Studies, Negev, Israel.

For Information: Prof. Arie Issar, Chairman of the Water Resources Center, The Blaustein International Center for Desert Studies, Ben-Gurion University of the Negev, Sede-Boqer Campus, Negev, Israel.

GEOREF INFORMATION SPECIALIST TRAINING (Falls Church, Virginia, U.S.A. A special program lasting $1-4$ months according to particular circumstances.

For Information: American Geological Institute, One Skyline Place, 5205 Leesburg Pike, Falls Chureh, VA 22041 , U.S.A.

HYDROLOGY (Brussels, Belgium). One-year diploma course and two-year Master's degree course under Interuniversity Postgraduate Program. Fellowships available. Language: English. For Information: Prof. A. Van Ler Beken, Program in Hydrology, Free University, Pleinlaan 2, B-1050 Brussels, Belgium.

$$
\$ \$ \$ \$ \$
$$

1985 - 101 pages - Eight colour plates

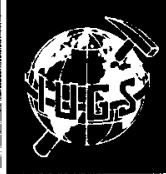

THE CAMBRIAN SYSTEM IN AUSTRALIA, ANTARCTICA AND NEW ZEALAND

Correlation Charts and Explanatory Notes

by

John Shergold, Jim Jago, Roger Cooper, and John Laurie

Sponsored by the International Commission on Stratigraphy

Subcommission on Cambrian Stratigraphy, Cambrian Correlations Working Group

Editors: J. H. Shergold

A. R. Palmer

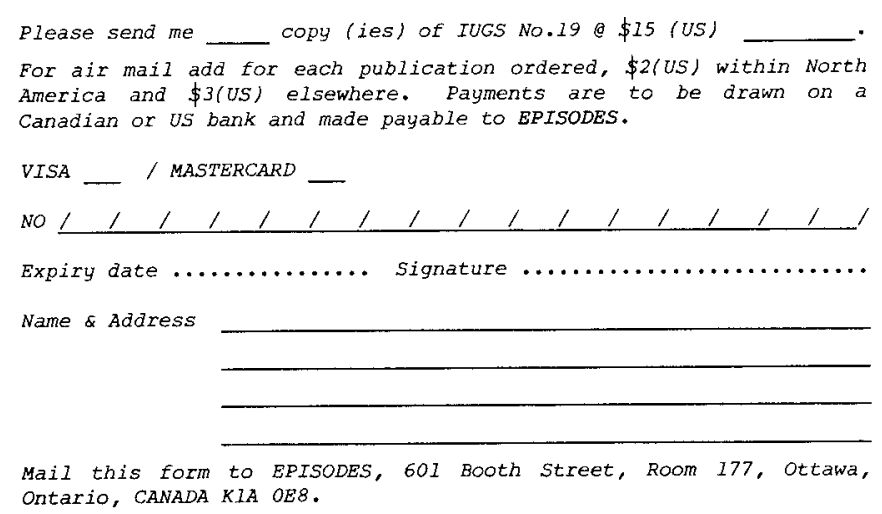

Ontario, CANADA KIA OEB. 


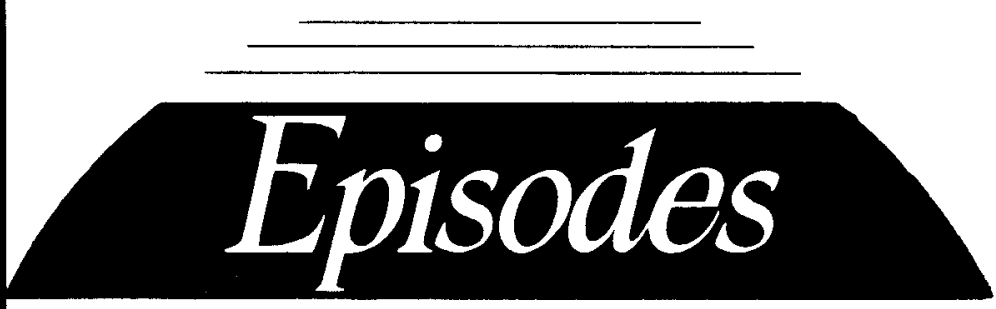

EARTH SCIENTISTS must contend with rapidly advancing knowledge and an ever-growing information base. They must also keep pace with a bewildering diversity of organizations and a wide array of conferences, seminars and workshops.

EPISODES helps solve these problems by covering both scientific and organizational news. Feature articles contributed by leading geoscientists from all parts of the world - review developments at the frontiers of the earth sciences.

EVERY issue includes reports on new developments in international earth science. Other standard features (e.g. book reviews, training courses, coming events) emphasize the resource aspect of the newsmagazine.

IF you are interested in what is going on globally in the geosciences, you should be reading Episodes on a regular basis.
Global Standards in Stratigraphy

Forecasting Volcanic Eruptions

The Kola Super-Deep Drill Hole

Chinese Loess \& Paleoclimates

Precambrian Paleosols

The Origin of Tethys

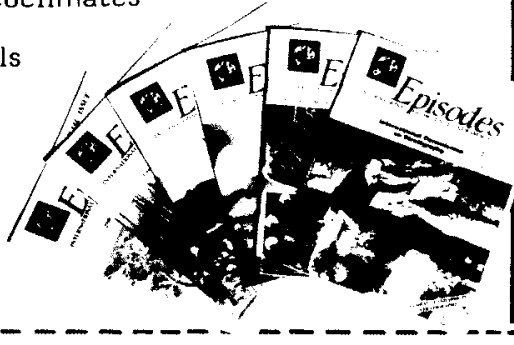

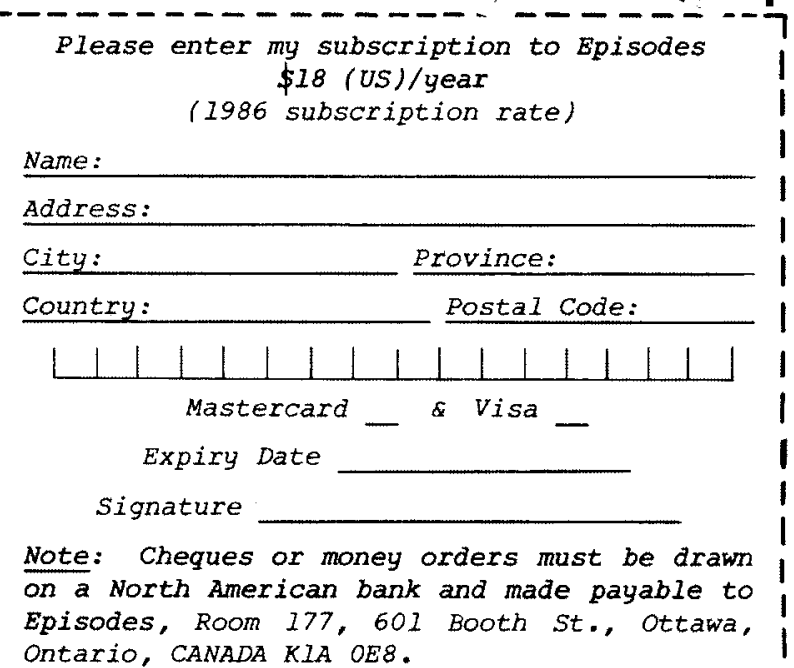

\title{
Your Window to the World
}

\section{Marine and Petroleum Geology}

\author{
published jointly by Butterworths and the Geological Society
}

The last fifteen years has seen a radical expansion in petroleum exploration activity throughout the world, paralleled by substantial and allied growth in marine geological and geophysical research. Successful petroleum exploration now requires full integration and application of many diverse techniques and concepts arising from subdisciplines within geology, geophysics and geochemistry. Innovative theoretical models of basin evolution and studies of modern environments can have equally relevant and important applications.

The scope of MARINE AND PETROLEUM GEOLOGY is comprehensive and includes original papers on marine geology, petroleum geology, geophysics and geochemistry.

MARINE AND PETROLEUM GEOLOGY provides an international forum for the exchange of multidisciplinary concepts and techniques of direct relevance to all concerned with marine and petroleum geology. It is ESSENTIAL READING for geologists, geophysicists and explorationists in industry, government and academia working in the following fields:

- Marine geology

- Sedimentary geology

- Basin analysis and evolution

- Continental margins
- Organic geochemistry

- Physical properties of sediments

- Reserve/resource estimation

- Geophysical interpretation
- Seismic stratigraphy

- Structural geology/tectonics

- Thermal models of basin evolution

- Formation evaluation techniques

- Well logging
Editor-in-Chief

Dr. D.G. Roberts, British Petroleum, London, UK
US Regional Editor

Dr. D. Scholl, US Geological Survey, California, USA

For further details and a sample copy please contact:-

Mrs. Sheila King, Butterworth Scientific Ltd, PO Box 63, Westbury House, Bury Street, Guildford, Surrey GU2 $5 B H$, UK Telephone: 048331261. 